orders of flowering plants. It was possible to assign most of them to natural orders and, in a few instances, to existing genera. 234 species were described in the original work of 1933 : most were assigned to new genera and species. Miss Chandler now adds a dozen new genera and more than a hundred new species to the list. There are, in all, more than 50 natural orders represented in the London Clay. The geographical distribution of these orders today suggested that the London Clay flora was that of a tropical rain forest with a similar floristic composition to that of the present Indo-Malayan region. The Tethys Sea at that time included the present Mediterranean and extended from the Indian Ocean to western Europe, and this flora spread along the adjacent land areas. Miss Chandler's later work fully supports these views.

But, in addition to supplementing our knowledge of the London Clay flora, Miss Chandler makes important additions to our knowledge of the other Palæocene floras of England.

The Second World War interrupted much of her work, but in the previous eight years and in the period after 1944 much collecting has been done and there are many interesting and useful data about new localities. In the present work under review we find a systematic treatment of the Early Tertiary floras of southern England from Thanet, Woolwich and Reading Beds of the Pre-Ypresian to the Ypresian with the Oldhaven, Blackheath Beds and the London Clay. The geological relationship of these beds and the separate basins of the London and Hampshire areas is clearly explained. Their floras all suggest tropical conditions. There is no evidence for supposing that a cool climate existed during the Palæocene.

The systematic descriptions of the floras and their species occupy about three-quarters of the volume and are treated in a similar manner to The London Clay Flora by Reid and Chandler. The volume of illustrations contains 34 plates, which include more than 1,030 excellent reproductions of photographs of fruits and seeds.

Miss Chandler is to be congratulated on a great achievement. The work is marked throughout by accuracy, and the descriptions are always clear and unambiguous.

JOHN WALTON

\section{K. TERZAGHI: FOUNDER OF THE SCIENCE OF SOIL MECHANICS}

From Theory to Practice in Mechanics Soil Selections from the writings of Karl Terzaghi. With bibliography and contributions on his life and achievement prepared by L. Bjerrum, A. Casagrande, R. B. Peck and A. W. Skempton. Pp. viii + 425. (New York and London: John Wiley and Sons, Inc., 1960.) 96s.

DROF. KARL TERZAGHI is one of the most interesting figures in the world of engineering science, and many believe him to be the greatest civil engineer of our day. Due to his pioneering research in Istanbul, leading to the publication of Erdbaumechanik in 1925, the study of the mechanical properties of soil was given a rational basis, and the science of soil mechanics, which is now studied by civil engineering students throughout the world, took its place among the other engineering disciplines.
Soil mechanics is itself divided into a number of specialities, for example the stability of earth dams, the design of pavements, the heaving of soil due to frost, etc., and it is astonishing how many of these various topics were first tackled systematically by Terzaghi, leaving it to others to develop along the lines he first indicated. This might have been deduced from his Soil Mechanics in Engineering Practice (1948); but it is brought out very clearly in this collection of his early papers, which trace in a fascinating way the development of soil mechanics, as we now know it, with the man. To the younger generation Terzaghi is already becoming a mythical figure. His James Forrest Lecture at the Institution of Civil Engineers in 1939 stirred their elders into a realization that soil mechanics was of vital concern to them ; now, in this work, all may come closer into contact with him and learn from his directness and integrity.

A few of the collected papers published here would have been available to readers in a big city with a good library. But the Proceedings of the First Soil Mechanics Conference (1936) are somewhat rare, and many will welcome the opportunity of having Terzaghi's contributions to it on their own shelves. Most of the other papers will be quite new, however, and of these the professional reports are the most valuable. Apart from their interest they provide a model of good prose.

The book has two particularly valuable sections. One, contributed by Prof. Skempton, assesses the importance of the concept of effective stress, discovered by Terzaghi, from which so much of the theory of soil mechanics is derived. The other, by Prof. Casagrande, is a biography of Terzaghi, which fills in some of the detail of the image which surrounds him. As he approaches his eightieth year, we are grateful to those who made this collection and edited the work. Few men of this stature emerge in each generation. Kevin Nash

\section{MELBOURNE SYMPOSIUM ON ANTARCTIC METEOROLOGY}

\section{Antarctic Meteorology}

Proceedings of the Symposium held in Melbourne, February 1959. (Commonwealth of Australia : Bureau of Meteorology.) Pp. xviii +483 . (London and New York: Pergamon Press, 1960. Published for and on behalf of the Director of Meteorology, Melbourne, Australia.) 105s. net.

TO criticism of the contributors to scientific symposia such as the one here presented would be implied by the comment that, in some cases, it may be doubted whether the papers are of such lasting value as to justify a hard-covered book selling at a high price. There are, after all, the appropriate scientific journals as media for publication. This particular symposium was, however, a special case, held under the official auspices of the Special Committee for the International Geophysical Year and the Special Committee for Antarctic Research shortly after the conclusion of the International Geophysical Year.

The symposium (Nature, 183,$1503 ; 1959$ ) was in fact a meeting of workers from the International Geophysical Year expeditions, then on their way home. In view of the fact that it was held so soon after the 